DOI https://doi.org/10.30525/978-9934-571-83-1-5

\title{
FEATURES OF DISCIPLINARY LIABILITY OF A PROSECUTOR IN THE CONTEXT OF CRIMINAL JUSTICE REFORM IN UKRAINE
}

\author{
Horzov A. P.
}

\section{INTRODUCTION}

The processes of European integration, which Ukraine is now undergoing, as well as the orientation of the legal policy of our state towards approaching European standards, according to which each member state should include in its domestic law the principles underlying the legislation of the European Union, have conditioned the prosecutor's office reform in Ukraine.

The transformation of the legal framework for the prosecutor's office commenced with the adoption of the Law of Ukraine "On Prosecutor's Office" on 14 October 2014, which made adjustments to the administrative and legal status of a prosecutor, in particular, to the legal mechanism of his/her disciplinary liability.

Under the conditions of bringing the legal framework for the prosecutor's office of Ukraine into line with European standards, the range of powers of prosecutors and heads of prosecutor's offices was changed, and the legal grounds for the functioning of the newly created collegial body in the prosecution service - the Qualification and Disciplinary Commission of Public Prosecutors - were instituted.

A significant breakthrough in addressing the administrative and legal status of a prosecutor was achieved with clearly defined guarantees of the independence of a prosecutor, including a special procedure for bringing him/her to disciplinary liability. The Qualification and Disciplinary Commission of Public Prosecutors considers and resolves disciplinary cases through disciplinary proceedings applying the special administrative and legal procedure provided by law. Thus, specifying concept, principles, and nature of functioning of the Qualification and Disciplinary Commission of Public Prosecutors, as well as its administrative and legal status, is also relevant today.

The new procedure for disciplinary proceedings and imposing disciplinary sanctions requires a scientific understanding of the concept of the administrative and legal status of a prosecutor. It is also necessary to study the problems of functioning of the legal mechanism of disciplinary liability of a prosecutor.

Cases of professional misconduct and ethics rules violation by prosecutors are detrimental to the state and the authority of the prosecution service, and adversely affect the trust of Ukrainian citizens in the representatives of this state 
institution. In order to improve the prosecutorial discipline, it is necessary to discuss proposals for optimizing the legal framework for educative work with them, as well as the improvement of the system of measures aimed at preventing disciplinary offenses committed by prosecutors.

In view of the ongoing process of reform, there is a need to develop a new approach to discussing the controversial issues as well as to conduct their indepth study. Thus, the monograph focuses on theoretical and legal, as well as on methodological research into the administrative and legal status of a prosecutor and his/her disciplinary liability in administrative and legal science in the context of defining the principles, concept, and nature of prosecutorial disciplinary liability. The main stages of formation of the institute of prosecutorial disciplinary liability in Ukraine are analyzed. The foreign experience of the legal framework for bringing a prosecutor to disciplinary liability is highlighted. The legal basis for the administrative and legal status and functioning of the Qualification and Disciplinary Commission of Public Prosecutors is described. The scientific and legal grounds for optimizing the legal framework for disciplinary liability of a prosecutor and improving the legal support of the functioning of the Qualification and Disciplinary Commission of Public Prosecutors are established.

\section{Disciplinary proceedings against a prosecutor: legal framework and implementation mechanism}

Disciplinary liability is incurred in each particular case of discipline violation as a result of law enforcement activities through determining the circumstances of the case, collecting necessary materials and evidence, their verification, identifying the existence of legal and factual grounds for liability ${ }^{1}$.

Disciplinary proceedings are carried out by the Qualification and Disciplinary Commission of Public Prosecutors (the Commission). As specified in Art. 45 "Disciplinary Proceedings against a Public Prosecutor" of the Law of Ukraine "On Prosecutor's Office" of 14 October $2014^{2}$, disciplinary proceedings are a procedure of reviewing by the Commission of a complaint (application), which contains information on a disciplinary offense committed by a prosecutor.

The Commission being an independent elected body in the prosecution service can conduct an impartial review of information and circumstances of a disciplinary proceeding against a prosecutor.

Disciplinary proceedings, as a complex of interconnected and interdependent procedural actions, require a high degree of legal and procedural regulations.

\footnotetext{
${ }^{1}$ Подкопаєв С., Сирай М. Проблеми законодавчого регулювання дисциплінарної відповідальності судді. Вісник національної академії прокуратури України. 2011. № 2. С. 84.

Про прокуратуру : Закон від 14 жовтня 2014 р. / Верховна Рада України. URL: http://zakon4.rada.gov.ua.
} 
The main tasks of disciplinary proceedings are the following:

- the timely, comprehensive, complete and objective investigation aimed at determining the circumstances of each disciplinary offense and solving the case within current legislation of Ukraine in order to prevent the violation of professional conduct rules and to strengthen discipline;

- identification of causes and factors contributing to committing disciplinary offenses;

- prevention of disciplinary offenses;

- ensuring the execution of decisions in disciplinary proceedings.

To perform these tasks, it is crucial to follow the principles of disciplinary proceedings in the prosecution service, which are prescribed by law or can be deduced from the content of normative legal acts regulating the relevant legal relationships. The following principles of disciplinary proceedings are worth mentioning:

- legality principle, which is set forth by the Constitution of Ukraine and which specifies that the State and all its institutions and officials follow the provisions of the Fundamental Law and act in line with the national legislation. This principle unites procedural law and substantive law aspects. The procedural aspect lies in the obligation of the participants in proceedings to adhere to the procedures established for the specific cases. The substantive aspect lies in the necessity to decide on disciplinary actions on the basis of norms to be applied in the particular case;

- publicity principle, according to which each participant in the proceeding has the right to freely access and study any disciplinary case materials, be present at its consideration, provide his/her explanations concerning the behavior being the reason for the application of disciplinary actions, taking into account the relevant restrictions on the disclosure of any information that constitutes the secret protected by law;

- respect for human dignity principle derives from the general requirement for state institutions and their officials to respect the person, his/her honor and dignity. This principle lies in the obligations of the participants in disciplinary proceedings when deciding on the application of disciplinary actions to take into account all circumstances of the case;

- ensuring the right to defense principle is connected with the fact that all state institutions and their officials under all circumstances ensure the protection of citizens' rights and freedoms. Moreover, the participants in disciplinary proceedings have the right to appeal against any decision, which in their opinion, violates their rights or legitimate interests;

- objectivity principle in disciplinary proceedings manifests itself in the requirement for the persons having the disciplinary powers to apply all 
contained in the normative legal acts measures to conduct a comprehensive and complete investigation into the cases on imposing disciplinary sanctions on the employees of the prosecutor's offices;

- expediency principle arises from the right of the head of the prosecutor's office, set forth in the normative legal acts, to choose the most expedient, in his/her opinion, alternative of behavior. This principle states that the disciplinary proceeding commences at the discretion of the head of the prosecutor's office, who further decides which disciplinary action and through which procedure to impose on each particular person;

- efficiency principle, which is conditioned by the necessity to promptly respond to violations of the code of professional conduct and ethics committed by the employees of the prosecutor's offices. This principle manifests itself in the less complicated, even in comparison to the administrative proceedings, procedure of reviewing cases on imposing the disciplinary sanctions on prosecutors;

- cost-effectiveness principle of disciplinary proceedings suggests that reviewing disciplinary cases and imposing disciplinary sanctions are subject to almost no financial and organizational expenditure on processing cases ${ }^{3}$.

In accordance with the Law of Ukraine "On Prosecutor's Office" of 14 October 2014 (the Law) ${ }^{4}$, disciplinary proceedings consist of the following stages: investigation into information concerning the existence of the specific grounds for bringing a prosecutor to a disciplinary liability, opening of a disciplinary case, consideration of the disciplinary proceeding and making decision by the body in charge of carrying out such disciplinary proceedings.

In our opinion, such stage of the disciplinary proceeding as initiating the question about the disciplinary liability of a prosecutor by members of the Commission can be distinguished.

Art. 45 of the Law $^{5}$ defines the pool of persons who have the right to appeal to the Commission with a complaint (application) against a prosecutor who has committed a disciplinary offense. As provided by the above-mentioned article, everyone, who is aware of disciplinary offenses committed by prosecutors, has the right to address the Commission with such a complaint. However, this person has to follow the provisions of the law on the proper filing of such a complaint (application concerning the violation of prosecutorial discipline). If a person fails to comply with the established requirements for the complaint

\footnotetext{
${ }^{3}$ Пшонка А. Дисциплінарна відповідальність прокурорів : автореф. дис. ... канд.. юрид. наук: 12.00.10. Харків, 2006. 22 с. С. 12.

4 Про прокуратуру : Закон від 14 жовтня 2014 p. / Верховна Рада України. URL: http://zakon4.rada.gov.ua.

Про прокуратуру : Закон від 14 жовтня 2014 p. / Верховна Рада України. URL: http://zakon4.rada.gov.ua.
} 
(application), he/she will be denied acceptance of the application or its further processing by the Commission member.

Thus, according to the Law, the persons who have the right to initiate the questions about bringing a prosecutor to the disciplinary liability for professional conduct and ethics violation, are the following: a citizen, a people's deputy (Parliament Member), a head of the state executive, local selfgovernment, enterprise, institution or organization, irrespective of subordination and forms of ownership, a representative of mass media with information about the disgraceful act committed by the employees of a prosecutor's office, as well as about the events with their participation, which may cause the public outcry.

It should be noted that the Law does not specify the procedure for submitting collective complaints (applications) by associations of citizens and society.

In case if the complaint (application) about the disciplinary misconduct committed by a prosecutor is lodged by the member of the Commission, he/she has no right to decide on the opening of the disciplinary proceeding, to carry out the investigation and to participate in voting when making a decision on the results of consideration of the conclusion on the existence or absence of a prosecutorial disciplinary offense ${ }^{6}$.

The Commission is also obliged to ensure the protection of personal data of prosecutors.

Consequently, as defined in the Law, it is forbidden to disclose the personal data of a prosecutor against whom the complaint was filed, i.e. his/her full name, until the decision in the case.

As provided by Art. 46 of the $\mathrm{Law}^{7}$, the Commission is empowered to open a disciplinary proceeding and to conduct an investigation into a complaint (application).

Thus, the secretariat of the Commission registers a complaint (application) on the day of its receipt and, using an automated system, determines the member of the Commission who will decide on opening of a disciplinary proceeding.

Until the completion of a disciplinary proceeding, a prosecutor cannot be dismissed from the position of a prosecutor on the grounds of filing of a letter of resignation by such a prosecutor ${ }^{8}$.

The prosecutors under the disciplinary proceeding and/or their representative have the following rights:

- to provide explanations or to refuse to provide them;

\begin{tabular}{|c|c|c|c|c|c|c|c|c|c|c|c|}
\hline $\begin{array}{c}6 \text { Про прокуратуру } \\
\text { http://zakon4.rada.gov.ua. }\end{array}$ & & Закон & від & 14 & жовтня & 2014 & p. / & Верховна & Рада & України. & URL: \\
\hline $\begin{array}{l}7 \text { Про прокуратуру } \\
\text { attp://zakon4.rada.gov.ua. }\end{array}$ & : & Закон & від & 14 & Жовтня & 2014 & & Верховна & Рада & України. & URL: \\
\hline $\begin{array}{c}\text { Про прокуратуру } \\
\text { tttp://zakon4.rada.gov.ua. }\end{array}$ & & Закон & від & 14 & жов & 2014 & & Зерховна & ада & України. & \\
\hline
\end{tabular}


- to question the participants in the proceeding;

- to lodge objections;

- to submit petitions;

- to file an application for recusal in case of doubts about the impartiality and objectivity of the member of the Commission? .

According to Art. 48 of the Law $^{10}$, the Commission adopts a decision in disciplinary proceedings by a majority of votes of its members. Before deciding, the Commission discusses the results of the opinion on existence or absence of the prosecutor's offense in the absence of the prosecutor who is the subject to the proceedings and other invited persons.

When making a decision in the disciplinary proceeding, members of the Commission take into account the nature of the offense, its consequences, the personality of the prosecutor, the degree of his/her guilt, and the circumstances affecting the choice of the type of the disciplinary sanction.

The decision of the Commission is stated in writing and signed by the Chairperson and members of the Commission who took part in the review of the opinion on the existence or absence of a disciplinary offense and is announced at the meeting of the Commission. The decision that follows the disciplinary proceeding includes the next data: the full name and position of the prosecutor brought to the disciplinary liability; the circumstances established in the course of the proceeding; the grounds upon which the Commission has made the decision; the summary of the decision pointing to the type of disciplinary sanctions in case of its imposition; procedures and terms of appeal against the decision. If any member of the Commission has a dissenting opinion, it is stated in writing and attached to the file, about what the Chairperson informs at the meeting. The content of such minority report is not to be disclosed at the meeting. A copy of the minority report is handed over to the prosecutor against whom the disciplinary proceeding was instituted.

A copy of the Commission decision is handed to the prosecutor in question or in a seven-day period is sent to him/her by a registered letter with a statement of receipt. During the same period a copy of the decision is sent to the head of the prosecutor's office, where the prosecutor in question is employed. The decision of the Commission, adopted on the results of the consideration of the disciplinary proceeding, is made public on its official web site within a sevenday period.

\footnotetext{
9 Про прокуратуру : Закон від 14 жовтня 2014 p. / Верховна Рада України. URL: http://zakon4.rada.gov.ua.

10 Про прокуратуру : Закон від 14 жовтня 2014 p. / Верховна Рада України. URL: http://zakon4.rada.gov.ua.
} 


\section{Legal framework and structure of the administrative and legal status of the Qualification and Disciplinary Commission of Public Prosecutors}

The existence of legal framework for legal relations is the main manifestation of the regulatory policy of the state in all spheres of the life of a society. The regulatory policy of Ukraine is manifested in a certain law-making activity, which lies in the adoption of normative legal acts, improvement and modernization of certain legal norms.

In connection with the reorganization and modernization of the prosecutor's office on 14 October 2014 the Law of Ukraine "On the Prosecutor's Office" was adopted, which set forth the procedure for bringing prosecutors to the disciplinary liability and the legal framework for the Qualification and Disciplinary Commission of Public Prosecutors operation. Thus, in accordance with Art. 73 of the Law ${ }^{11}$, to ensure the disciplinary proceeding the creating and functioning of the Commission is foreseen.

The prosecution service of Ukraine performs functions set forth in the Constitution of Ukraine to protect rights and freedoms of a person, as well as essential interests of the society and the state. These functions are fulfilled by prosecutors - the employees of the prosecutor's offices with class ranks, who carry out official duties according to the Constitution of Ukraine, the Law of Ukraine "On the Prosecutor's Office", procedural and other laws, as well as in accordance with the secondary legislation (legal documents of the Prosecutor's General Office of Ukraine).

According to Art. 19 of the Law, the prosecutor is obliged ${ }^{12}$ to have respect for persons while exercising his/her powers; not to disclose information that constitutes a secret protected by law; to act only on the basis, within and in the manner prescribed by the Constitution and laws of Ukraine; to adhere to the rules of the prosecutorial ethics, in particular to prevent behavior that discredits $\mathrm{him} / \mathrm{her}$ as a representative of the prosecutor's office and may harm the authority of the prosecutor's office.

The Law of Ukraine "On the Prosecutor's Office" provides the following grounds for bringing a prosecutor to the disciplinary liability:

- failure to perform or improper performance of official duties;

- unreasonable delay in consideration of applications;

- disclosure of secrets protected by law which became known to the prosecutor while exercising his/her powers;

- violation of the legal procedures for submission of the declaration of assets, income, expenses and financial obligations;

\footnotetext{
11 Про прокуратуру : Закон від 14 жовтня 2014 р. / Верховна Рада України. URL: http://zakon4.rada.gov.ua.

12 Про прокуратуру : Закон від 14 жовтня 2014 р. / Верховна Рада України. URL: http://zakon4.rada.gov.ua.
} 
- actions which discredit the prosecutor and may raise doubts on his/her objectivity, impartiality and independence, as well as on integrity and incorruptibility of prosecution service;

- regular (twice or more times within one year) or one gross violation of prosecutorial ethics;

- violation of internal service regulations;

- intervention or any other influence of a prosecutor in cases or in the manner other than established by the law in the work of another prosecutor, staff member, official or judge, including through public statements about their decisions, actions or inactions in the absence of signs of an administrative or criminal offense;

- public statement violating the presumption of innocence ${ }^{13}$.

In case there are grounds for the disciplinary liability and a complaint (application) containing information about committing of a disciplinary offense by a prosecutor is lodged, the disciplinary proceeding is commenced. In accordance with the Law, disciplinary proceedings are conducted by the Qualifications and Disciplinary Commission of Public Prosecutors.

The Law provides qualitatively new approaches to defying the bases for prosecution service operation and ways of their implementation, the prosecution service organization, procedure for appointment to the position of a prosecutor and dismissal of a prosecutor from an administrative position, the mechanism of his/her disciplinary liability, the functioning of the Commission.

The Commission is the newly created collegial body in the prosecution service of Ukraine, which performs certain powers regarding the staffing of the prosecutor's offices. Thus, this recently created institute addresses certain matters of human resource management in the prosecution service, i.e. the disciplinary liability of a prosecutor, transferring of prosecutors and their dismissal from the office ${ }^{14}$.

Research into the administrative and legal status of the Qualification and Disciplinary Commission of Public Prosecutors as well as the creation of this body in the context of the prosecution service reform at the moment remains one of less developed and ambiguous issues in modern legal science. At the same time, according to the Law, the Commission has special powers that are important for the staffing of the prosecutor's offices, therefore, the study of the structure of the administrative and legal status of the Qualification and Disciplinary Commission of Public Prosecutors remains relevant.

\footnotetext{
13 Про прокуратуру : Закон від 14 жовтня 2014 p. / Верховна Рада України. URL: http://zakon4.rada.gov.ua.

${ }^{14}$ Горзов А., Долгий О. Адміністративний та правовий аспекти кадрового забезпечення прокуратури України в умовах прокурорського самоврядування. Митна справа. 2015 . № 2 (2.1). С. 146.
} 
Thus, according to Chapter 3 of the Law of Ukraine "On Prosecutor's Office" of 14 October $2014^{15}$, the Qualification and Disciplinary Commission of Public Prosecutors is a collegial body that, according to the powers granted by the Law, determines the level of professional training of those individuals who have expressed their intention to hold a position of a prosecutor and addresses matters of their disciplinary liability, transferring and dismissal.

The collegial nature of the Commission is conditioned by the features of its composition. Thus, the Commission is composed of eleven members, who are to be the citizens of Ukraine, have a university degree in law and at least ten years of professional legal experience.

The Commission consists of the following members:

- five public prosecutors appointed by the All-Ukrainian Conference of Public Prosecution Employees;

- two persons (scientists) appointed by the Conference of Representatives of Law Universities and Academic Institutions;

- one person (a defense lawyer) appointed by the Conference of Defense Lawyers;

- three persons appointed by the Ukrainian Parliament Commissioner for Human Rights following an approval by the Verkhovna Rada committee responsible for issues of prosecution service organization and operation.

As it was mentioned above the All-Ukrainian Conference of Public Prosecution Employees appoints five members of the Qualification and Disciplinary Commission of Public Prosecutors as specified in Art. 74 "Members of the Qualification and Disciplinary Commission of Public Prosecutors". This body of prosecutorial self-government appoints five members of the Commission. Moreover, this article establishes requirements for members of the Qualification and Disciplinary Commission of Public Prosecutors. They must be the citizens of Ukraine, possess higher legal education and have at least ten years of professional legal experience. In addition, this article also defines the restrictions on the work in the Commission. Thus, a member of Ukrainian Parliament, a representative of the Cabinet of Ministers of Ukraine, central or local executive, a researcher or a professor of the National Prosecution Academy of Ukraine, other educational or academic institution managed by the prosecution service, a judge, a law enforcement or government supervisory authority officer or a public prosecutor holding an administrative position cannot be appointed a member of the Commission.

It should also be taken into account that:

\footnotetext{
15 Про прокуратуру : Закон від 14 жовтня 2014 p. / Верховна Рада України. URL: http://zakon4.rada.gov.ua.
} 
1) a member of the Qualification and Disciplinary Commission of Public Prosecutors cannot at the same time be a member of the Council of Public Prosecutors of Ukraine;

2) one and the same person cannot exercise the powers of a member of the Commission for two consecutive terms.

The scientific definition of the status and powers of the Qualification and Disciplinary Commission of Public Prosecutors is impossible without defining the general concept of the administrative and legal status and its main elements.

The nature, structure and content of a legal status as of the key concept of legal science are always the subject of study both by scientists and practitioners. In legal literature, there are several approaches to defining the content of the category "legal status" and its structure. Thus, before considering the issue of determining the structure of the administrative and legal status and powers of the Qualification and Disciplinary Commission of Public Prosecutors, in our opinion, there is a need to investigate the concepts of "legal status" and "administrative and legal status".

The concept "legal status" is the status of a subject in some legal relations and it depends on the specified in law rights, competencies, tasks and liability. Moreover, the elements of the structure of legal status are interdependent and interactive.

The status of the Qualification and Disciplinary Commission of Public Prosecutors is set forth in Art. 73, Chapter 3, Section VII of the Law of Ukraine "On Prosecutor's Office"". Thus, according to the article, the Commission assesses the level of professional training of individuals willing to become public prosecutors, and decides on disciplinary liability, transfer and dismissal of public prosecutors.

Consequently, the above-mentioned chapter of the law defines the Commission as the most important link in human resource management in the prosecution service of Ukraine, as the effective staffing of the local prosecutor's offices with employees who meet the requirements for professional training, legal experience and state language knowledge, as well as staffing of regional prosecutor's offices and the Prosecutor General's Office of Ukraine with employees who meet the requirements of the Art. 27 of the Law of Ukraine "On Prosecutor's Office" depend on the effective operation of the Qualification and Disciplinary Commission of Public Prosecutors.

In addition, the Commission addresses issues of disciplinary liability, the transfer and dismissal of prosecutors. The Commission has certain, defined in the law, set of legally established powers, rights and duties concerning the

\footnotetext{
16 Про прокуратуру : Закон від 14 жовтня 2014 р. / Верховна Рада України. URL: http://zakon4.rada.gov.ua.
} 
disciplinary liability of prosecutors, which determine its place in the system of the prosecution service of Ukraine.

In legal science, there is no unified approach to determining the structure of the legal status of state authorities and collegial bodies formed in state authorities for solving particular issues. In state and non-governmental organizations, legal capacity manifests itself in the competence of their bodies, that is, in the set of their rights and obligations, granted to them to perform the respective functions ${ }^{17}$. Consequently, the competence of the Commission is one of the main elements that defines and characterizes its legal status.

According to M. Rassolov, the elements of legal status include a set of rights and freedoms, obligations and liability that establish the legal status of a body or a specific person in society ${ }^{18}$. Yu. Bytiak includes defined by the law rights and obligations, guarantees and liability for non-fulfillment of duties to the main elements of legal status ${ }^{19}$.

Thus, the elements of the legal status of the Commission are competence (rights, obligations and liability), purpose, tasks, functions, structure and membership of this collegial body.

The Commission is a legal entity, it has the seal with the National Emblem of Ukraine and its legal name, independent balance sheet and accounts with the State Treasury of Ukraine, it is given full civil capacity, can enter into relations with state authorities and local self-government, legal and natural persons, to conclude contracts, may be a plaintiff and defendant in court (Art. 80 of the Civil Code of Ukraine of January 16, 2003, № 435-IV).

The status (legal capacity) of the Commission is determined by Arts. 73-79 of the, according to which the Commission, in its legal form, is a permanent collegial independent body of public authority with selectively assigned members and is empowered to determine the level of professional training of those individuals who have expressed their intention to hold a position of a prosecutor and addresses matters of their disciplinary liability, transferring and dismissal.

The Commission is granted the rights of a legal entity from the moment of its state registration and its legal capacity terminates from the date of entering the record on its termination to the Uniform State Register (Art. 91 of the Civil Code of Ukraine).

\footnotetext{
17 Загальна теорія держави і права : навчальний посібник / за заг. ред. В. Копєйчікова. Київ : ЮрінкомІнтер, 2000. $320 \mathrm{c}$.

${ }^{18}$ Теория государства и права : учебник для вузов / под ред. М. Рассолова, В. Лучина, Б. Эбзеева. Москва : Юнити-Дана, 2001. 640 с. С. 217.

${ }^{19}$ Битяк Ю. Державна служба та розвиток ії демократичних основ. Харків : Українська юридична академія, 1990. 74 с. С. 43.
} 
The Commission acquires and exercises the rights and duties of a legal entity through its Chairperson (Art. 78 of the Law), who acts faithfully and reasonably on behalf and in interests of the Commission, not exceeding his/her powers (Art. 92 of the Civil Code of Ukraine).

There are also peculiarities in the formation of the Commission. According to the law, a member of Ukrainian Parliament, a representative of the Cabinet of Ministers of Ukraine, central or local executive, a researcher or a professor of the National Prosecution Academy of Ukraine, other educational or academic institution managed by the prosecution service, a judge, a law enforcement or government supervisory authority officer or a public prosecutor holding an administrative position cannot be appointed a member of the Commission.

The powers of the members of the Commission include the following:

- to file complaints (applications) about the disciplinary offense committed by the prosecutor;

- to decide on the opening of disciplinary proceedings;

- to refuse to open a disciplinary proceeding by a motivated decision;

- to make a decision to open a disciplinary proceeding against a prosecutor;

- to carry out an investigation within the circumstances reported in the complaint (application);

- to appeal to the Commission with a request to remove the prosecutor from office until the disciplinary proceeding is finished;

- to prepare opinions following the investigation into the existence or absence of a disciplinary misconduct.

Moreover, in course of considering of the disciplinary case, the Commission may make a motivated decision on the need for a prosecutor's attestation.

On the basis of competence and powers (set of rights and obligations) of the Commission, as contained in the $\mathrm{Law}^{20}$, it is possible to determine the following functions, which reveal the directions of the Commission activity:

The function of staffing the prosecutor's offices (the Commission makes a decision to start the enrollment of candidates for a position of a prosecutor, organizes the acceptance of applications and documents from candidates, conducts the entrance exams, announces the competition to fill vacancies, submits the application to the head of the local prosecutor's office concerning the appointment of a candidate for a position of a prosecutor (Art. 29), holds a competition to transfer the prosecutor to another prosecutor's office, including to a prosecutor's office of a higher level, to a vacant or temporarily vacant position (p. 1, Art. 38), submits a motion to the President of Ukraine to dismiss the Prosecutor General of Ukraine from office following a court decision which

\footnotetext{
20 Про прокуратуру : Закон від 14 жовтня 2014 p. / Верховна Рада України. URL: http://zakon4.rada.gov.ua.
} 
found him/her guilty of committing an administrative corruption offense (p. 2, Art. 54), etc.

Jurisdictional function (the Commission carries out disciplinary proceedings against prosecutors (Art. 44), including the consideration of complaints (applications), which contain information on the prosecutor's disciplinary offense (Art. 45), the adoption of a decision on imposing a disciplinary sanction or decision of the impossibility of his/her further tenure in the prosecutor's position (p.4, Art. 48), the conduction of disciplinary proceedings, the revision of the conclusion on the existence or absence of a disciplinary offense, the adoption of a decision concerning a prosecutor in question, the consideration of the issue of the violation of the requirements for prosecutors regarding incompatibility (for example, the Commission may make a decision on the existence of grounds for the removal of the prosecutor from office until the completion of a disciplinary proceeding, on the basis of which the head of the prosecutor's office, where the prosecutor is employed, may issue an order for his/her removal (p. 5, Art. 46), etc.

The norm-making function (this function manifests itself through the adoption of subordinate legal acts, the failure to comply with which may lead to negative consequences for the relevant actors (candidates for the position of a prosecutor, prosecutors, the Commission itself), for example, the approval by the Commission of the procedure for passing of the qualification exam and the methodology for evaluating the results of the qualification opinion concerning the activities of the prosecutor (p. 6, Art. 31), the approval of the form and content of the application for participation in the enrollment of candidates for the position of a prosecutor (p. 1.1 of Art. 30), etc.

The function of documentation and control (recording of data on the number of vacant or temporarily vacant posts in the prosecutor's office (p. 1.6 of Art. 9, p. 1.5 of Art. 11, p.1.3 of Art. 13), ensuring the verification of exam papers after the examination and determining the number of points scored on the qualification exam by candidates for the position of a prosecutor (p. 4, Art. 31), as well as conducting a special examination of candidates for the position of a prosecutor who have successfully passed the qualification exam (p. 1, Art. 32), etc.

The procedure for the work of the Commission is governed by the Regulations adopted by the All-Ukrainian Conference of Public Prosecutor's Offices Employees in accordance with Art. 70 of the Law. The secretariat of the Commission supports its organizational operation.

In view of everything mentioned above, we propose the definition of the structure of the administrative and legal status of the Qualification and Disciplinary Commission of Public Prosecutors as of an integral part of its social status, which defines its legal status as a collegial body in the system of the 
prosecution service of Ukraine, which has official manifestation in the law, formal certainty and the procedure for the membership formation on the basis of their election, and is characterized by a systemic definition of powers and functions, includes certain legal elements, in particular rights and obligations, competencies, functions and powers.

The doctrine of the administrative and legal status of the Qualification and Disciplinary Commission of Public Prosecutors and its legal nature is important for the development of scientific and methodological issues of legal science, as well as for the scientific basis for the development of subordinate legal acts that will regulate the procedure for its activities.

The Commission is a collegial body in the system of the prosecution service of Ukraine, which addresses the issue of disciplinary liability of prosecutors and must ensure guarantees of the independence of prosecutors, protecting them from making unreasonable decisions concerning conduction of disciplinary proceedings and the imposition of disciplinary sanctions.

\section{CONCLUSIONS}

The new approach to the legal regulation of the disciplinary liability of the prosecutor set forth in the Law of Ukraine "On the Prosecutor's Office" has partially solved such legal problems as the application of disciplinary actions, the establishment of guarantees of reasonable implementation of disciplinary liability, ensuring of certain stability in the prosecution system, but it has also identified theoretical problems regarding the powers of the members of the Qualification and Disciplinary Commission of Public Prosecutors and the implementation of their opinion about the existence of a disciplinary offense committed by a prosecutor.

The legal framework for the disciplinary liability of a prosecutor which is specified in the Law of Ukraine "On the Prosecutor's Office" and other normative legal acts of the prosecutor's office of Ukraine also indicates that there is no legal mechanism for conducting investigations into information regarding a disciplinary offense by a prosecutor, which complicates the process of exercising the powers of the members of the Commission and the activity of Commission in general.

The legal grounds for the application of disciplinary sanctions as of measures of moral influence on prosecutors are not provided in the legislation, therefore, further improvement of the legal framework for disciplinary liability of prosecutors should be manifested in the provisions which will provide for a legal mechanism for the implementation of the specified measures.

The disciplinary sanctions in the prosecution service of Ukraine can be imposed on prosecutors, in particular on the employees of the prosecutor's 
offices who are subject to the norms of the Law of Ukraine "On Prosecutor's Office" regarding the status of an employee of the prosecutor's office, but in the legal framework for the prosecutor's offices of Ukraine lacks provisions that contain peculiarities of conducting disciplinary proceedings, imposing of disciplinary sanctions on such categories of employees as the Prosecutor General of Ukraine, Deputy Prosecutor General of Ukraine, scientific and pedagogical employees of the National Prosecution Academy of Ukraine, as well as on a separate category - civil servants of the prosecutor's offices.

Moreover, the features of conducting disciplinary proceedings and imposing disciplinary sanctions on prosecutors of military prosecutor's offices and the Specialized Anti-Corruption Prosecutor's Office require the elaboration of additional legal framework.

Such means of preventing the violation of professional conduct and ethics rules as notice to cease the unethical behavior has no specified procedure for its application.

The opinion of the Commission concerning the dismissal of a prosecutor from office is of a recommendatory nature, which the Prosecutor General of Ukraine, a head of the local or regional prosecutor's office may take into account when considering the case.

\section{SUMMARY}

The processes of European integration, which Ukraine is now undergoing, have conditioned the prosecutor's office reform in Ukraine. One of the key elements of this reform is the provisions concerning the disciplinary proceedings and the start of the Qualification and Disciplinary Commission of Public Prosecutors operation in 2017. Under the conditions of bringing the legal framework for the prosecutor's office of Ukraine into line with European standards, the range of powers of prosecutors and heads of prosecutor's offices was changed, and the legal grounds for the functioning of the newly created collegial body in the prosecution service - the Qualification and Disciplinary Commission of Public Prosecutors - were instituted.

The Qualification and Disciplinary Commission of Public Prosecutors is a collegial body that, according to the powers granted by the Law, determines the level of professional training of those individuals who have expressed their intention to hold a position of a prosecutor and addresses matters of their disciplinary liability, transferring and dismissal.

The legal framework for the prosecution service of Ukraine lacks the legal mechanism of conducting investigations into information concerning the disciplinary offense committed by a prosecutor that challenges the powers of the members of the Qualification and Disciplinary Commission of Public 
Prosecutors and the operation of this body. Moreover, the relevant legislation contains no peculiarities of conducting disciplinary proceedings, imposing of disciplinary sanctions on such categories of employees as the Prosecutor General of Ukraine, Deputy Prosecutor General of Ukraine, scientific and pedagogical employees of the National Prosecution Academy of Ukraine, as well as on a separate category - civil servants of the prosecutor's offices.

The opinion of the Commission concerning the dismissal of a prosecutor from office is of a recommendatory nature, which the Prosecutor General of Ukraine, a head of the local or regional prosecutor's office may take into account when considering the case.

\section{REFERENCES}

1. Битяк Ю. Державна служба та розвиток іï демократичних основ. Харків : Українська юридична академія, 1990. 74 с.

2. Горзов А., Долгий О.О. Адміністративний та правовий аспекти кадрового забезпечення прокуратури України в умовах прокурорського самоврядування. Митна справа. 2015. № 2 (2.1). С. 143-148.

3. Загальна теорія держави і права : навчальний посібник / за заг. ред. В. Копєйчікова. Київ : Юрінком-Інтер, 2000. 320 с.

4. Подкопаєв С., Сирай М. Проблеми законодавчого регулювання дисциплінарної відповідальності судді. Вісник національної академії прокуратури України. 2011. № 2. С. 83-86.

5. Про прокуратуру : Закон від 14 жовтня 2014 р. / Верховна Рада України. URL: http://zakon4.rada.gov.ua.

6. Пшонка А. Дисциплінарна відповідальність прокурорів : автореф. дис. ... канд. юрид. наук: 12.00.10. Харків, 2006. С. 22.

7. Теория государства и права : учебник для вузов / под ред. М. Рассолова, В. Лучина, Б. Эбзеева. Москва : Юнити-Дана, 2001. 640 с.

\section{Information about author:}

Horzov A. P.,

$\mathrm{Ph}$. D. in Law,

Deputy Head of the Department of Continuous Training of Civil Servants of the Public Prosecution Service Institute for Continuing Professional Development

National Prosecution Academy of Ukraine 81b, Yurii Illienko str., Kyiv, 04050, Ukraine 